\title{
The value of glucocorticoid co-therapy in different rheumatic diseases - positive and adverse effects
}

\author{
Marlies C van der Goes*, Johannes W Jacobs and Johannes W Bijlsma
}

\begin{abstract}
Glucocorticoids play a pivotal role in the management of many inflammatory rheumatic diseases. The therapeutic effects range from pain relief in arthritides, to disease-modifying effects in early rheumatoid arthritis, and to strong immunosuppressive actions in vasculitides and systemic lupus erythematosus. There are multiple indications that adverse effects are more frequent with the longer use of glucocorticoids and use of higher dosages, but high-quality data on the occurrence of adverse effects are scarce especially for dosages above $10 \mathrm{mg}$ prednisone daily. The underlying rheumatic disease, disease activity, risk factors and individual responsiveness of the patient should guide treatment decisions. Monitoring for adverse effects should also be tailored to the patient. Continuously balancing the benefits and risks of glucocorticoid therapy is recommended. There is an ongoing quest for new drugs with glucocorticoid actions without the potential to cause harmful effects, such as selective glucocorticoid receptor agonists, but the application of a new compound in clinical practice will probably not occur within the next few years. In the meantime, basic research on glucocorticoid effects and detailed reports on therapeutic efficacy and occurrence of adverse effects will be valuable in weighing benefits and risks in clinical practice.
\end{abstract}

\section{Introduction}

The value of glucocorticoid therapy was discovered 65 years ago. In 1949, Philip Hench reported the dramatic effect of compound $\mathrm{E}$ on rheumatoid arthritis (RA) [1]. Nowadays, glucocorticoids play a pivotal role in the management of many inflammatory rheumatic diseases [2-7]. Glucocorticoids represent the most frequently

*Correspondence: m.c.vandergoes@umcutrecht.nl

Department of Rheumatology \& Clinical Immunology (F02.127), University Medical Center Utrecht, PO Box 85500, 3508 GA Utrecht, the Netherlands employed class of anti-inflammatory drugs, with a rise in use in recent years [8-11], despite the development of new treatment modalities such as biological drugs applicable for many rheumatic diseases. Community survey data indicate use of glucocorticoids among $0.5 \%$ of the general population, and $1.4 \%$ of women aged older than 55 years [12,13]. Between 14.6 and $90 \%$ of patients with RA worldwide are undergoing treatment with glucocorticoids [10]. Almost all patients with polymyalgia rheumatic, giant cell arteritis and systemic vasculitis use systemic glucocorticoids.

Glucocorticoids are very effective anti-inflammatory and immunosuppressive drugs, but their use is restrained by fear for and occurrence of adverse effects (Figure 1).

\section{Mechanisms of action}

The effects of glucocorticoids are thought to be mediated by different mechanisms [14-19]. Classic genomic mechanisms leading to changes in gene expression are most important in low-dose therapy (see Figure 2) [20]. These actions occur after passage of glucocorticoid molecules through the cell membrane, binding to the inactive cytosolic glucocorticoid receptor, formation of an activated glucocorticoid-cytosolic glucocorticoid receptor complex, and translocation of this complex into the nucleus. Transactivation and transrepression can be initiated in the nucleus. Transactivation is caused by binding of two activated glucocorticoid-cytosolic glucocorticoid receptor complexes as a dimer to the promotor of glucocorticoid-regulated genes, which leads to upregulation of the synthesis of certain regulatory proteins by transcriptional activation. In transrepression, glucocorticoid-cytosolic glucocorticoid receptor monomer complexes interfere with the activity of (proinflammatory) transcription factors such as activator protein 1 and nuclear factor- $\mathrm{kB}$, leading to downregulation of (proinflammatory) protein synthesis. Genomic processes require at least 30 minutes before changes can be observed in regulatory protein synthesis, but usually it will take hours to days for changes to occur at the cell, tissue or organ level $[18,21]$.

The repressive, anti-inflammatory effects of glucocorticoids were believed until recently to be based mainly on 


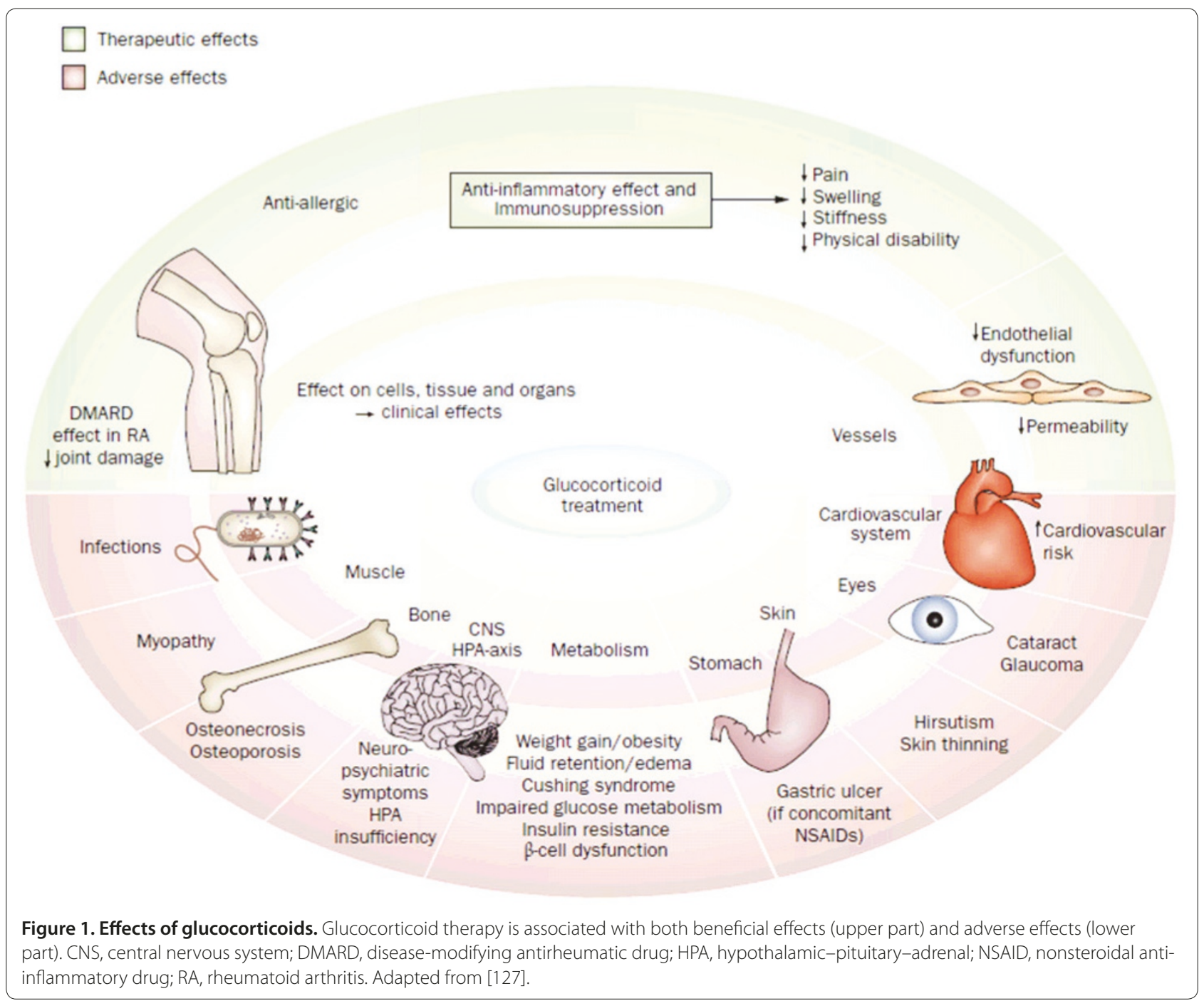

transrepression [19], whereas the negative effects - with the exception of infection risk - and metabolic actions of glucocorticoid therapy were based on transactivation. This view has been somewhat revised, with the suggestion that some key anti-inflammatory actions of glucocorticoids are caused by gene activation [19,22]. Moreover, research in a mouse strain with a deficiency in forming dimer glucocorticoid-glucocorticoid receptor complexes, and thus with a transactivation deficiency, showed - along with a failure of glucocorticoids to exert a full anti-inflammatory response - classic side effects such as osteoporosis in these mice [23].

In very high-dose therapy, nongenomic mechanisms also occur, effects of which are evident within minutes [20]. These nongenomic mechanisms are mediated via the cytosolic glucocorticoid receptor, via the membranebound glucocorticoid receptor, and via nonspecific interactions with membranes of cells and organelles, including those of mitochondriae.
The size of genomic effects of glucocorticoid preparations defines their dose equivalence. Dexamethasone and betamethasone are the most potent preparations, followed by methylprednisolone, predniso(lo)ne, cortisol and cortisone [20]. Dosages of specific glucocorticoid preparations often are expressed in relation to the potency of the most frequently used preparation; that is, prednisone. The definitions of low-dose therapy through to pulse therapy are presented in Table 1.

\section{Patterns of glucocorticoid use}

Glucocorticoid use (dose, duration, administration) depends on the diagnosis, indications for glucocorticoid therapy, and the goal of treatment (see Table 2). The therapeutic effects range from pain relief in arthritides, to disease-modifying effects in early RA, and to strong immunosuppressive actions in vasculitides and systemic lupus erythematosus (SLE). Not all effects have been studied in detail. 


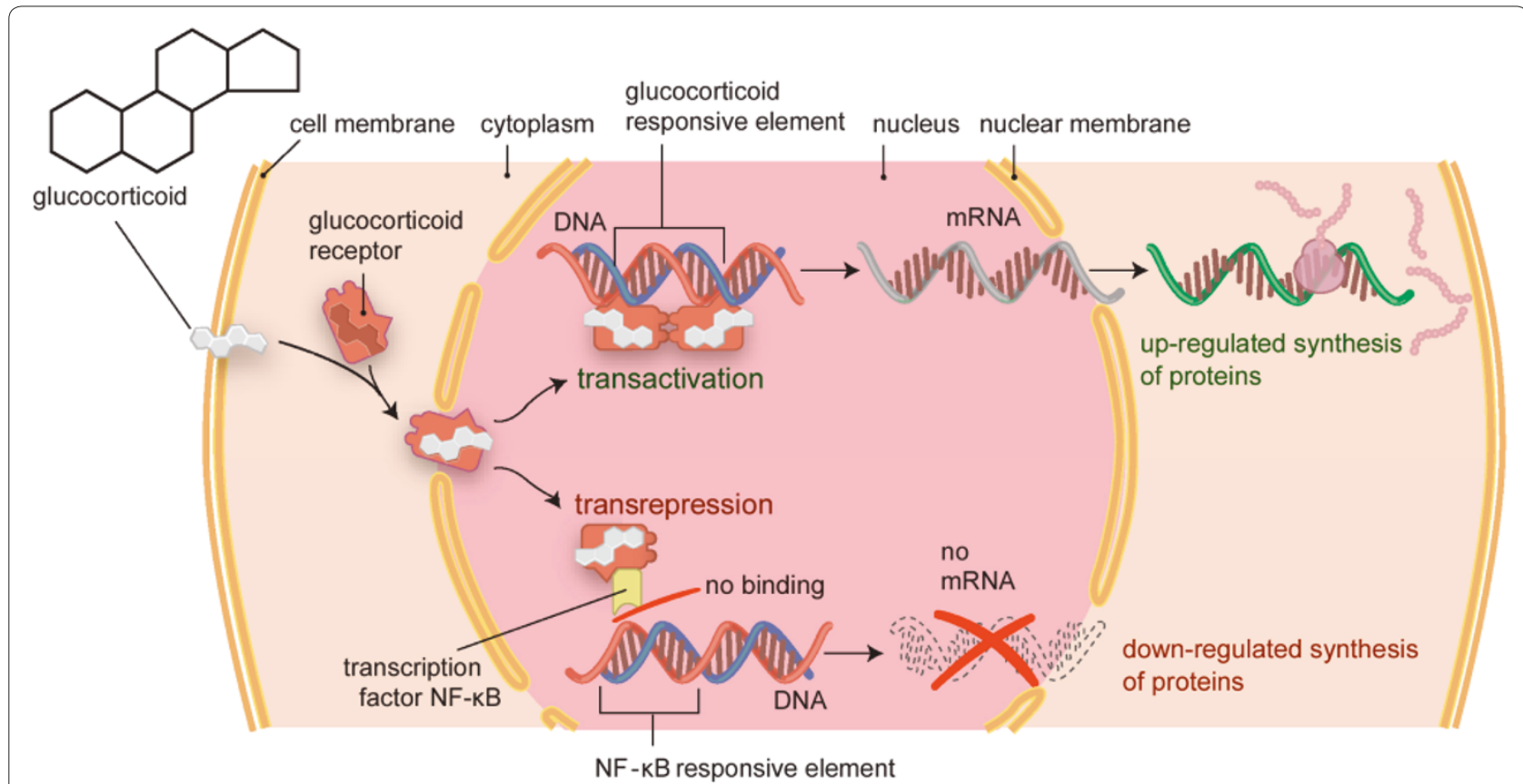

Figure 2. Genomic action of glucocorticoids. Glucocorticoid binds to the glucocorticoid receptor (GCR) in the cytoplasm. This complex migrates into the nucleus. Activation of transcription (transactivation) by binding of GCR-glucocorticoid complex dimers to glucocorticoid-responsive elements of DNA upregulates synthesis of regulatory proteins, thought to be responsible for metabolic effects and also some anti-inflammatory/ immunosuppressive effects. Interaction of GCR-glucocorticoid complex monomers with proinflammatory transcription factors, such as activator protein-1, interferon regulatory factor-3 and nuclear factor (NF)-kB, leads to inhibition of binding of these transcriptional factors to their DNA consensus sites (for NF-KB: NF-KB-responsive elements). The transcription of these proinflammatory transcription factors is thus repressed. This process is called transrepression and downregulates synthesis of predominantly inflammatory/immunosuppressive proteins. Adapted from [128].

\section{Primary immunosuppressive treatment with glucocorticoids}

Glucocorticoids are anchor drugs for therapeutic strategies in myositis, polymyalgia rheumatica and systemic vasculitis. For other rheumatic diseases, glucocorticoids are adjunctive therapy, or are not used at all. Monotherapy with glucocorticoids is applied in polymyalgia rheumatica; remission can often be achieved with treatment starting at $15 \mathrm{mg}$ prednisone or equivalent daily [24].

Glucocorticoids also represent the most important class of drugs in giant cell arteritis. For this disease, higher initial dosages are often used (mostly 40 to $60 \mathrm{mg}$ prednisone or equivalent daily). Furthermore, in the case of (transient) acute visual loss, pulse therapy is applied.

In the treatment of polymyalgia rheumatica and giant cell arteritis, other immunomodulatory drugs are sometimes added to glucocorticoids as glucocorticoid-sparing agents to decrease the dose or duration of glucocorticoid therapy. However, the results of research into the glucocorticoid-sparing properties of other immunosuppressive medication - that is, use of other agents to decrease the cumulative glucocorticoid dose - are not convincing. Outcomes of randomized controlled trials in polymyalgia rheumatica on the glucocorticoid-sparing effects of methotrexate [25-27], azathioprine [28] and infliximab
Table 1. Definition of conventional terms for glucocorticoid dosages

\begin{tabular}{ll}
\hline Dose & Definition \\
\hline Low & $\leq 7.5 \mathrm{mg}$ prednisone equivalent/day \\
Medium & $>7.5 \mathrm{mg}$ but $\leq 30 \mathrm{mg}$ prednisone equivalent/day \\
High & $>30 \mathrm{mg}$ but $\leq 100 \mathrm{mg}$ prednisone equivalent/day \\
Very high & $>100 \mathrm{mg}$ prednisone equivalent/day \\
Pulse therapy & $\geq 250 \mathrm{mg}$ prednisone equivalent/day for 1 day or a few days
\end{tabular}

Adapted from [20].

[29] were conflicting. The same holds true for adjunctive treatment with methotrexate [30-32], cyclosporine [33], etanercept [34] and infliximab [35] in giant cell arteritis. A recent retrospective study in 23 patients indicated that leflunomide is effective as a glucocorticoid-sparing agent in patients with difficult-to-treat giant cell arteritis and polymyalgia rheumatic, but this still needs to be confirmed in randomized controlled trials [36].

\section{Combination therapy including glucocorticoids Pulse therapy}

Acute episodes or particularly severe forms of rheumatic diseases and specific complications are indications for pulse therapy. In collagen disorders, pulse therapy is 
Table 2. General use of glucocorticoids in rheumatology

\begin{tabular}{|c|c|c|c|c|c|}
\hline & \multicolumn{3}{|c|}{ Initial oral dose } & \multirow{2}{*}{$\begin{array}{l}\text { Intravenous, } \\
\text { very high dose } \\
\text { or pulse therapy }\end{array}$} & \multirow{2}{*}{$\begin{array}{l}\text { Intra-articular } \\
\text { injection }\end{array}$} \\
\hline & Low & Medium & High & & \\
\hline \multicolumn{6}{|l|}{ Arthritides } \\
\hline Gouty arthritis, acute & - & 2 & 2 & - & 2 \\
\hline Juvenile idiopathic arthritis & - & 1 & 1 & - & 1 \\
\hline Osteoarthritis & - & - & - & - & 1 \\
\hline Acute calcium pyrophosphate crystal arthritis & - & - & - & - & 2 \\
\hline Psoriatic arthritis & - & 1 & - & - & 2 \\
\hline Reactive arthritis & - & - & - & - & 1 \\
\hline Rheumatic fever & - & 1 & 1 & - & - \\
\hline Rheumatoid arthritis & 2 & 2 & 1 & 1 & 2 \\
\hline \multicolumn{6}{|l|}{ Collagen disorders } \\
\hline Dermatomyositis, polymyositis & - & - & 3 & 1 & - \\
\hline Mixed connective tissue disease & - & 1 & - & 1 & 1 \\
\hline Polymyalgia rheumatica & - & 3 & - & 1 & - \\
\hline Sjögren's syndrome, primary & - & - & 1 & - & - \\
\hline Systemic lupus erythematosus & - & 2 & 1 & 1 & - \\
\hline Systemic sclerosis & - & 1 & - & - & - \\
\hline \multicolumn{6}{|l|}{ Systemic vasculitides } \\
\hline In general & - & - & 3 & 1 & - \\
\hline
\end{tabular}

Initial dose, the dose at the start of therapy, will often be decreased in time depending on disease activity: low, $\leq 7.5 \mathrm{mg}$ prednisone equivalent/day; medium, $>7.5$ but $\leq 30 \mathrm{mg}$ prednisone equivalent/day; high, $>30$ but $\leq 100 \mathrm{mg}$ prednisone equivalent/day; very high, $>100 \mathrm{mg}$ prednisone equivalent/day. - , rare use; 1 , infrequent use, for therapy-resistant disease, complications, severe flare, major exacerbation, and for bridging the lag-time of recently started therapy; 2 , frequently added to/used as the basic therapeutic strategy; 3, basic part of the therapeutic strategy. With permission from BMJ publishing group [129].

applied for disease induction or treatment of flares. In RA, pulse therapy is used to treat serious complications of the disease and to induce remission in active disease. In the latter, it makes sense to simultaneously start a new second-line antirheumatic treatment aiming at stabilizing the remission induced by pulse therapy, since the beneficial effects generally last about 6 weeks [37]. There are several different schemes of pulse therapy. Pulse therapy with schemes of $1,000 \mathrm{mg}$ methylprednisolone intravenously has proven effective in many studies.

\section{High and medium doses}

In systemic vasculitis, high-dose glucocorticoids are the cornerstone of induction therapy and the therapy of flares. Usually, other immunosuppressive drugs are applied simultaneously. In this chronic treatment, the dosages (often starting with $1 \mathrm{mg} / \mathrm{kg}$ body weight prednisone equivalent) are gradually reduced in weeks to months to a maintenance therapy of low to medium dose.

Another application of high-dose glucocorticoids is intermittent treatment; for example, in gout to treat attacks. In a gout attack, treatment with $35 \mathrm{mg}$ prednisone during 5 days improved pain scores, as did treatment with naproxen [38]. Glucocorticoids are stopped in the periods between these attacks, although there are a few exceptions. For example, glucocorticoids can be used in patients with gout as a bridge for adequate suppression of uric acid in cases where nonsteroidal antiinflammatory drugs (NSAIDs) and colchicine are contraindicated.

\section{Low dose}

Chronic glucocorticoid therapy in RA is often started and maintained at a low dose, mostly in addition to other disease-modifying antirheumatic drugs. Glucocorticoid therapy is highly effective for relieving symptoms in patients with active RA in the short and medium term $[39,40]$. Improvement has been documented for all clinical parameters, including pain scales, joint scores, morning stiffness and fatigue, but also in parameters of the acute phase reaction (that is, erythrocyte sedimentation rate and C-reactive protein). Use of a modifiedrelease preparation at bedtime (that is, releasing the administered glucocorticoid in the early morning, similar to the circadian rhythms of endogenous cortisol) leads to even more improvement in morning stiffness than use of a conventional tablet of equal dosage taken after awakening [41]. After 6 months of therapy, the beneficial effects of glucocorticoids in general seem to diminish. However, clinical experience suggests that if this therapy 
is then tapered off and stopped, some patients experience clear aggravation of symptoms and signs, indicating that the beneficial effect was still present before tapering. In reports, very low doses of glucocorticoids (that is, $<5 \mathrm{mg}$ prednisone equivalent/day) can be sufficient for patients to remain in remission without causing severe adverse events [42]. However, the risk-benefit ratio of this therapy with very low doses has not been studied in a prospective randomized way.

Recent studies have (re)established the disease-modifying potential of low-dose glucocorticoids in early RA and have renewed the debate on benefits and risks of this treatment [43-52]. Beneficial effects of initial glucocorticoid treatment during the first 2 years of the disease on retardation of joint damage are still present after 4 to 5 years [53-55], which has not been shown for any other disease-modifying antirheumatic drug. As such, glucocorticoids can be used for helping to achieve remission and prevent joint damage in the long term; they are part of the management for early RA according to European guidelines [56]. Surprisingly, evidence for the efficacy of glucocorticoids was not incorporated in the 2012 update of the American College of Rheumatology treatment recommendations for RA [57], which is highly debatable [58].

\section{Local application of glucocorticoids}

Another type of use is local application of glucocorticoids. In persisting nonbacterial arthritis of a joint, intraarticular glucocorticoid injection can be considered. The effect depends on several factors, such as the treated joint (size, weight bearing, or non-weight bearing), the activity of arthritis and the volume of synovial fluid in the treated joint, the application of arthrocentesis (synovial fluid aspiration) before injection, the choice and dose of the glucocorticoid preparation, the injection technique, and application of rest to the injected joint [59].

Among the injectable glucocorticoids, triamcinolone hexacetonide is the least soluble preparation and showed the longest effect [60]. In a randomized controlled study, bed rest for 24 hours following injection of a knee joint in patients with inflammatory arthritis resulted in prolonged duration of clinical response and reduced the need for additional injections, compared with a control group that received no particular advice about activity with the injected joint [61]. Favorable effects of resting the injected joints (for example, by splinting in a cast or plaster) for 3 weeks in the case of a non-weight bearing (upper extremity) joint and 6 weeks for a weight bearing (lower extremity) joint have been described [62]. Based on the literature, no definite evidence-based recommendation can be made, but it seems prudent to rest and certainly not to overuse the injected joint for several days, even if pain is relieved [63].
An alternative to glucocorticoid therapy for intraarticular use has not yet been recognized.

\section{Adverse effects}

There is no doubt that glucocorticoids have a high potential for frequent and serious adverse events. Compared with other antirheumatic agents, glucocorticoids have a low incidence of short-term symptomatic toxicity and patients uncommonly discontinue therapy for this reason. There are multiple indications that adverse effects are more frequent with longer use of glucocorticoids and use of higher dosages $[64,65]$, but high-quality data on the occurrence of adverse effects are scarce especially for dosages above $10 \mathrm{mg}$ prednisone daily. Most published studies on glucocorticoid toxicity are retrospective and observational [66]. Systematic reviews and randomized controlled trials are considered the highest quality evidence, but these studies are often focused on treatment efficacy. They have not been powered or designed to assess toxicity. The inability to differentiate unfavorable outcomes attributable to glucocorticoids from those occurring as a complication of the disease treated or as co-morbidities also confounds the picture. Furthermore, there is strong selection bias for glucocorticoid use because physicians are inclined to treat patients with more severe disease with (higher dosages of) glucocorticoids (confounding by indication).

Therefore, despite over 60 years of use, robust data on toxicities of long-term glucocorticoid therapy are sorely lacking [67-70]. Fortunately, many of the adverse events can be avoided or dealt with if glucocorticoids are used prudently. An overview of positive as well as negative effects of glucocorticoid therapy is given in Figure 1.

In the following paragraphs, several notorious adverse effects of glucocorticoid therapy are discussed. These paragraphs will give an overview of frequently reported adverse effects in literature. Additionally, we will discuss the influence of disease and treatment scheme on the occurrence of adverse effects.

\section{Effects on bone \\ Osteoporosis}

Chronic oral treatment with more than $5 \mathrm{mg}$ prednisone daily can lead to a reduction in bone mineral density and an increase in the risk of fracture [71]. However, in many studies concerning glucocorticoid-induced osteoporosis, no attention is paid to the fact that glucocorticoids are usually prescribed for inflammatory diseases, which themselves have negative impact on bone mineral density.

Bone mineral density changes may develop in RA in the absence of glucocorticoid therapy. Previous findings suggest that bone loss in RA patients not on glucocorticoid therapy mainly occurs during the first months 
of disease [72,73]. Correlations with parameters of inflammation have been found in some studies [74-77]. Development of osteoporosis can thus also be caused by active early RA. In early RA, glucocorticoids have positive effects on bone [43,44,46-51]. The joint-sparing effect is probably based on the inhibition of proinflammatory cytokines such as interleukin-1 and tumor necrosis factor $[78,79]$, which have direct positive effects on osteoclast formation and stimulate osteoblasts and $\mathrm{T}$ lymphocytes to produce receptor activator of nuclear factor- $\mathrm{kB}$ ligand $[78,80]$. Binding of receptor activator of nuclear factor- $\mathrm{kB}$ ligand to its receptor (receptor activator of nuclear factor-kB) on osteoclast precursor cells leads to differentiation and activation of osteoclasts, and subsequently to bone resorption, periarticular osteopenia, and formation of bone erosions in patients with RA (see Figure 3) [78]. A recent study showed that the bone mineral density scores in the first years of treatment with low-dose glucocorticoids are similar to these scores in patients without glucocorticoid therapy, when preventive medication for osteoporosis has been used [77]. Preventive measures will be discussed in the section 'Recommendations for clinical practice'.

\section{Osteonecrosis}

For adverse effects on bone other than osteoporosis, a major limitation is that trials have not been powered or designed to assess toxicity or long-term effects, and therefore uncertainty of the true incidence and relevance of these adverse effects still remains. In general, osteonecrosis does not occur frequently. The frequency of occurrence clearly depends on the dose of glucocorticoid therapy and the underlying disease. Regarding pulse therapy, osteonecrosis seems to be a more frequent side effect in patients with SLE compared with patients with RA [81]. Both the disease and glucocorticoids therefore seem to play a role in osteonecrosis (especially) in SLE.

\section{Endocrine effects Weight gain and moon face}

In the case of long-term endogenous or exogenous glucocorticoid excess, patients can experience increased appetite. As a consequence, this may contribute to increased body and trunk fat, finally leading to a cushingoid appearance with centripetal fat accumulation and thin extremities with atrophic skin and contusions. A recent trial in RA with $10 \mathrm{mg}$ prednisone daily showed a small but significant gain in weight over 2 years, with a mean of $2.9 \mathrm{~kg}$ in the methotrexate-based strategy group treated with prednisone compared with $1.3 \mathrm{~kg}$ in the methotrexate-based strategy group treated with placeboprednisone [52]. Additional analyses showed that this body weight gain after treatment of active RA was, at least partly, regaining patients' previous weight by the reduction of the weight loss-inducing disease activity, which was more reduced in the prednisone strategy group [82].

The incidence of iatrogenic Cushing's syndrome is dependent on dose and duration of therapy. Development of a moon face is uncommon in therapy with subphysiologic dosages.

\section{Diabetes and cardiovascular disease}

Many doctors and patients are afraid of the development of diabetes during glucocorticoid therapy [83], and of the thereby increasing risk of cardiovascular events [84]. Cardiovascular disease is more prevalent in rheumatic patients than in the general population [85]. This increased prevalence is probably based on elevated levels of proinflammatory cytokines such as tumor necrosis factor alpha and interleukin- 6 in the systemic circulation, with multiple effects on organs, including adipose tissue, and endothelium [86]. These cytokines are also overproduced in dysfunctional adipose tissue of obese individuals [87]. The resulting cascade of changes throughout the body driven by systemic inflammation leads to a pro-atherogenic profile: atherogenic lipid abnormalities, oxidative stress, depletion of endothelial progenitor cells associated with impairment of vascular injury repair, increased arterial stiffness, insulin resistance, endothelial dysfunction, a hypercoagulable state, elevated homocysteine levels, and upregulation of atherogenic T cells [86].

In RA and SLE, markers of inflammation correlate with impaired insulin sensitivity and impaired beta-cell function [88-90]. Deterioration of glucose tolerance has not been observed for short-term glucocorticoid therapy at medium to high doses [91], which might be explained by the effectiveness of glucocorticoids in dampening the inflammation. The influence of glucocorticoid therapy at low to medium doses for multiple years on glucose metabolism seemed to be minor [92]. Based on these studies, one could conclude that glucocorticoids, if used to effectively treat an inflammatory condition, are not an important risk factor for the development of cardiovascular disease. However, in cases of overt diabetes before treatment, patients should be instructed to carefully monitor their blood glucose level shortly after starting glucocorticord therapy [69].

\section{Suppression of the hypothalamic-pituitary-adrenal axis}

Administration of glucocorticoids leads to negative feedback on the hypothalamus and pituitary glands, resulting in less secretion of corticotropin-releasing hormone and adrenocorticotropic hormone, respectively. As a result, the cortisol secretory capacity of the fasciculatereticularis zone of the adrenal cortex may decrease, since 


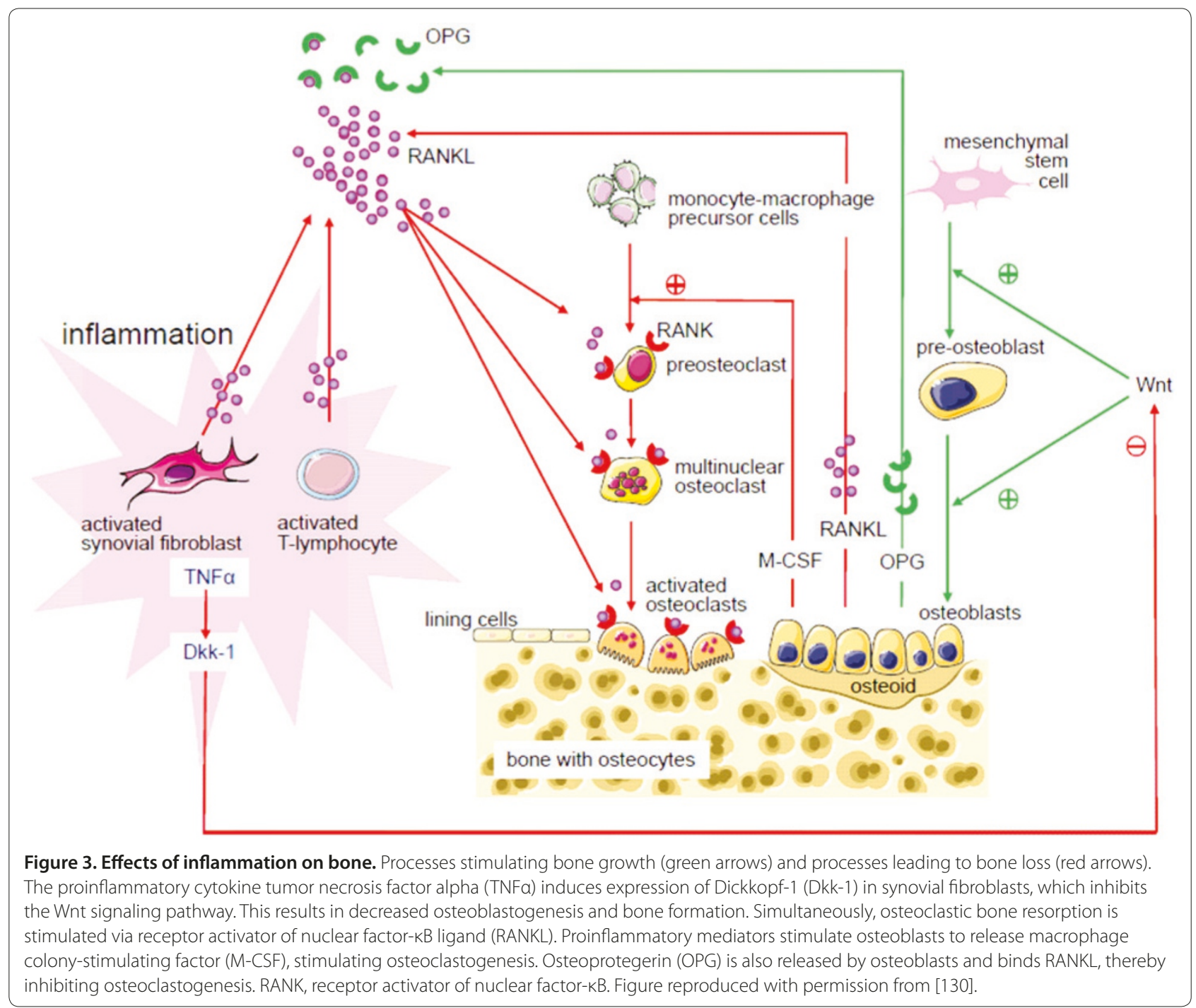

this inner cortical zone of cortisol production is dependent on adrenocorticotropic hormone for structure and function.

Prediction of the suppression of the hypothalamicpituitary-adrenal axis and tertiary adrenal insufficiency is not reliable, but their prevalence appears to depend on both the dose and duration of glucocorticoid treatment. In the case of long-term glucocorticoid therapy of up to $10 \mathrm{mg}$ prednisone or equivalent daily, the risk of symptomatic adrenal failure is not high, but also not negligible. In clinical practice, it seems appropriate to anticipate potential adrenal insufficiency in patients who received $7.5 \mathrm{mg}$ prednisone or equivalent for at least 3 weeks. Acute cessation of therapy could lead to problems. Gradual tapering of the glucocorticoid dose is therefore usually applied. In the case of suspected adrenal insufficiency, adrenocorticotropic hormone stimulation testing can help in evaluating the adrenal response [93].
Further, in the case of acute injury or stress (for example, with surgery), adequate adaptation of the glucocorticoid dose is important. Often a temporary increase of the dose to $15 \mathrm{mg}$ prednisone equivalent/day is sufficient for minor surgery.

\section{Infections}

Randomized clinical trials with glucocorticoids often report a not increased risk of infection [44,46,52,94,95]. However, cohort studies and case-control studies showed an increased occurrence of infections in patients with RA [96-99]. Moreover, the dose of glucocorticoid therapy and combination treatment with other immunosuppressive drugs further elevate the risk [96]. Data suggest that awareness of the risk of infections before and during glucocorticoid treatment is needed.

Both typical and atypical microorganisms can cause infections. Clinicians should realize that glucocorticoids 
may blunt classical clinical features of infection, and thereby delay the recognition of the infection and the start of treatment. Opportunistic infections with Pneumocystis jiroveci have been reported for dosages from $16 \mathrm{mg}$ prednisone equivalent daily during 8 weeks [100].

The performance of screening tests for infections, such as the tuberculin skin test and interferon gamma release assays, are suppressed by glucocorticoid therapy [101]. Furthermore, specific recommendations for vaccination in patients with inflammatory rheumatic diseases have been developed [102].

\section{Gastrointestinal problems Bleeds}

The risk of upper gastrointestinal tract bleeding or perforation increases about twofold with use of oral glucocorticoids or low-dose aspirin, and increases around fourfold with use of other NSAIDs [103]. This relatively high risk indicates that combined use of NSAIDs and glucocorticoids should be avoided, if possible [104]. If this combined treatment cannot be avoided, appropriate gastroprotective medication, such as proton pump inhibitors, helps to decrease the risk of bleeding and should be prescribed. In patients with low cardiovascular risk, cyclooxygenase- 2 inhibitors may be an alternative for NSAIDs and proton pump inhibitors, since they induce a lower risk of gastrointestinal complications in RA compared with NSAIDs [105-107].

\section{Other}

Cases of bowel perforation and pancreatitis have been reported in the context of glucocorticoid use. However, causality between the glucocorticoid therapy and these events is unsure; other factors such as the inflammatory disease might also play a role.

\section{Neuropsychiatric events}

Slight increases in sense of well-being are frequently reported by patients starting glucocorticoid therapy. Symptoms of acathisia, insomnia and depression have also been recorded. Similar to the risk of osteonecrosis, the risk of psychosis seems to be a more frequent side effect of pulse therapy in SLE patients compared with patients with RA [81]. Whether this increased incidence reflects an increased risk of this adverse effect of glucocorticoids in SLE or whether - and to what extent this increased incidence also reflects psychosis as a complication of the disease is uncertain.

\section{Dermatologic problems}

Easy bruising, ecchymoses, skin atrophy, striae, disturbed wound healing, acne and increased hair growth (excluding scalp hair) are undesirable dermatologic effects that occur with glucocorticoid therapy [108]. The physician often considers these changes to be of minor clinical importance, but they may be disturbing to the patient. No reliable data on the occurrence of these adverse effects are available.

\section{Ophthalmologic effects}

Posterior subcapsular cataract is a well-described complication of prolonged glucocorticoid use [109]. This type of cataract is also related to diabetes, but it is not typically age related. Cortical cataracts also have also been associated with glucocorticoid use.

Glucocorticoid-treated patients may develop mild increased intra-ocular pressure, which can lead to minor visual disturbances. The development of frank glaucoma, threatening eye sight, is rare for low-dose therapy, and tends to appear in patients who are otherwise predisposed to the condition. A higher risk for glaucoma with glucocorticoids tends to occur more frequently if other risk factors are present, such as a family history of glaucoma, high myopia and diabetes [69]. In these patients, even when initiating low-dose therapy, an ophthalmologist should be consulted before the start of therapy [69].

\section{Recommendations for clinical practice}

Safe glucocorticoid therapy is glucocorticoid treatment with optimal therapeutic effects and with minimal adverse effects. To facilitate safe use, recommendations for the management of glucocorticoid therapy in rheumatic diseases have been developed and have been published in recent years [68-70]. Adverse effects of glucocorticoids are partially avoidable. To avoid adverse events as much as possible, several measures can be taken.

\section{Education}

First, patients should be informed of what to expect from this therapy. Nowadays, patients are more articulate and stand up for themselves. They should be actively informed about the expectations on both positive and negative effects of treatment with glucocorticoids. This information should be given over time, in small steps. Ideally, this should be supported by written information. Hopefully, this will lead to neutralizing of unfounded fears, earlier recognition of true adverse effects, and patient compliance.

\section{Preventive measures}

Patients with or at risk of glucocorticoid-induced osteoporosis should receive appropriate preventive and/ or therapeutic interventions. In general, all patients starting glucocorticoid therapy at medium to high dose are at risk of developing osteoporosis. Calcium, (active) 
vitamin $\mathrm{D}$ and bisphosphonates have been proven effective in preventing and treating glucocorticoidinduced osteoporosis [110-115]. Preventive therapy with calcium and vitamin D should be started, because glucocorticoids impair bone mechanism - amongst other mechanisms - via inhibition of intestinal calcium absorption and renal tubular calcium reabsorption. Additionally, in general, bisphosphonates are indicated. Guidelines on indications and choices for specific drugs differ somewhat between countries.

Several algorithms have been developed to refine the estimate of the risk of fractures for individual patients, such as the Fracture Risk in Glucocorticoid-induced Osteoporosis score, which includes the glucocorticoid dosage taken, and $\mathrm{FRAX}^{\circ}$ fracture risk assessment [116-119], for which adjustments have also been suggested for glucocorticoid dosages $>7.5 \mathrm{mg}$ prednisone equivalent daily $[120,121]$. The decision of whether a patient should be treated depends on fracture risks and on the cost, effectiveness and safety of the treatment.

\section{Optimizing therapy}

The initial dose, dose reduction and long-term dosing depend on the underlying rheumatic disease, disease activity, risk factors and individual responsiveness of the patient [68]. Except for treatment with glucocorticoids in early RA as a disease-modifying antirheumatic drug, in which dosages of 5 to $10 \mathrm{mg}$ prednisone equivalent during 1 to 2 years are used, for prolonged treatment the glucocorticoid dosage should be kept to a minimum, and a glucocorticoid taper should be attempted in the case of remission or low disease activity; the reasons to continue glucocorticoid therapy should be regularly checked. The need for continuing glucocorticoid treatment should be under constant review, and the dose should be titrated against therapeutic response, risk of undertreatment, and development of adverse effects [70].

Optimal choices regarding the use of glucocorticoids in rheumatic diseases are patient specific. The underlying disease, the presence of co-morbidity, the response to initial treatment, and the development of adverse effects should influence treatment decisions. Monitoring for adverse effects should also be tailored to the patient: specific aspects of individual patients may warrant a higher frequency of monitoring or a more comprehensive set of adverse effects to be monitored. Continuously balancing the benefits and risks of glucocorticoid therapy is recommended.

\section{Use in pregnancy}

The fetus is protected from maternal glucocorticoids since glucocorticoids bound to proteins cannot pass the placenta, and the enzyme $11 \beta$-hydroxysteroid dehydrogenase in the placenta converts cortisol and prednisolone into the inactive 11-dehydro-prohormones. The prednisolone maternal-to-fetal blood concentration ratio is therefore about 10:1. The risk of adverse effects of antenatal exposure to glucocorticoids such as reduced intrauterine growth and birth weight, neurocognitive adverse effects and oral cleft seems dependent on the dose, preparation, duration of therapy and stage of pregnancy [122]. Avoiding high doses (such as 1 to $2 \mathrm{mg} / \mathrm{kg}$ prednisone equivalent) is advised in the first trimester of pregnancy, whereas low to moderate doses of prednisone seem to be safe $[122,123]$.

\section{Future}

New biological therapies have not replaced glucocorticoids, and probably will not replace them in the near future, as anchor drugs in therapeutic strategies for rheumatic diseases. Future research should therefore stay focused on the mechanisms causing beneficial and harmful effects and on predictive factors for the effects of glucocorticoids. Ultimately, response to glucocorticoids should preferably be predictable for the individual patient; studies on genomics and proteomics are being performed currently to this aim.

Apart from prediction of the treatment effects, there is an ongoing quest for new glucocorticoids without potential to cause harmful effects. Optimized glucocorticoids, such as selective glucocorticoid receptor agonists, are being developed to minimize the adverse effects many patients experience, especially if glucocorticoids are given at higher dosages over longer periods of time [124]. The most important approach to optimize the risk-benefit ratio of glucocorticoids is to understand in more detail how the molecular mechanisms of genomic and nongenomic glucocorticoid actions - and their dose dependency - mediate the clinically wanted benefits but also the known adverse effects [125]. During past years, it has become evident that separation of the beneficial effects from the harmful effects is a more complicated process than anticipated $[19,23]$. Further research on this topic is ongoing [126], but a breakthrough for clinical practice will probably not occur within the next few years.

In some decades to come, we will hopefully be able to prescribe new drugs with glucocorticoid actions with an improved risk-benefit ratio. Moreover, it might be possible to adjust the use of glucocorticoids and other medication to specific individual patients' needs, characteristics and prognostic factors: personalized medicine. This would lead to a more effective inhibition of the inflammatory diseases with less adverse effects. While this has not been achieved, basic research on glucocorticoid effects and detailed reports on therapeutic efficacy and occurrence of adverse effects will be valuable in weighing benefits and risks in clinical practice. 


\section{Conclusion}

Glucocorticoids are very effective anti-inflammatory and immunosuppressive drugs, but their use is restrained by fear for and occurrence of adverse effects. Many of the adverse effects can be avoided or dealt with when glucocorticoids are used prudently. Optimal choices regarding the use of glucocorticoids in rheumatic diseases are patient specific, as is monitoring for adverse effects. There is an ongoing quest for new glucocorticoids without the potential to cause harmful effects, such as selective glucocorticoid receptor agonists, but the application of a new compound in clinical practice will probably not occur within the next few years.

\section{Abbreviations}

NSAID, nonsteroidal anti-inflammatory drug; RA, rheumatoid arthritis; SLE, systemic lupus erythematosus.

\section{Competing interests}

The authors declare that they have no competing interests.

\section{Authors' contributions}

The authors participated in the design of and helped to draft the manuscript. All authors read and approved the final manuscript.

\section{Declaration}

This article has been published as part of Arthritis Research \& Therapy Volume 16 Suppl 2, 2014: At the interface between immunology and endocrinology in rheumatic diseases. The full contents of the supplement are available at http://arthritis-research.com/supplements/16/S2.

This supplement was proposed, developed and commissioned by Arthritis Research \& Therapy and was funded by an educational grant from Horizon Pharma Inc. All published articles were independently prepared by the authors and have undergone peer review in accordance with the journal's standard policies and processes. Horizon Pharma Inc had no input into the topics covered or the articles themselves. The Supplement Editor was appointed by the journal and declares that they have no competing interests.

Published: 13 November 2014

\section{References}

1. Hench PS, Kendall EC, Slocumb CH, Polley HF: The effect of a hormone of the adrenal cortex (17-hydroxy-11-dehydrocorticosterone; compound E) and of pituitary adrenocorticotropic hormone on rheumatoid arthritis. Mayo Clin Proc 1949, 24:181-197.

2. Bertsias G, loannidis JP, Boletis J, Bombardieri S, Cervera R, Dostal C, Font J, Gilboe IM, Houssiau F, Huizinga T, Isenberg D, Kallenberg CG, Khamashta M, Piette JC, Schneider M, Smolen J, Sturfelt G, Tincani A, van Vollenhoven R, Gordon C, Boumpas DT; Task Force of the EULAR Standing Committee for International Clinical Studies Including Therapeutics: EULAR recommendations for the management of systemic lupus erythematosus. Report of a Task Force of the EULAR Standing Committee for International Clinical Studies Including Therapeutics. Ann Rheum Dis 2008, 67:195-205.

3. Hatemi G, Silman A, Bang D, Bodaghi B, Chamberlain AM, Gul A, Houman MH, Kotter I, Olivieri I, Salvarani C, Sfikakis PP, Siva A, Stanford MR, Stübiger N, Yurdakul S, Yazici H; EULAR Expert Committee: EULAR recommendations for the management of Behcet disease. Ann Rheum Dis 2008, 67:1656-1662.

4. Mukhtyar C, Guillevin L, Cid MC, Dasgupta B, de Groot K, Gross W, Hauser T, Hellmich B, Jayne D, Kallenberg CG, Merkel PA, Raspe H, Salvarani C, Scott DG, Stegeman C, Watts R, Westman K, Witter J, Yazici H, Luqmani R; European Vasculitis Study Group: EULAR recommendations for the management of primary small and medium vessel vasculitis. Ann Rheum Dis 2009, 68:310-317

5. Mukhtyar C, Guillevin L, Cid MC, Dasgupta B, de Groot K, Gross W, Hauser T, Hellmich B, Jayne D, Kallenberg CG, Merkel PA, Raspe H, Salvarani C, Scott DG, Stegeman C, Watts R, Westman K, Witter J, Yazici H, Luqmani R; European
Vasculitis Study Group: EULAR recommendations for the management of large vessel vasculitis. Ann Rheum Dis 2009, 68:318-323.

6. Gorter SL, Bijlsma JW, Cutolo M, Gomez-Reino J, Kouloumas M, Smolen JS, Landewe R: Current evidence for the management of rheumatoid arthritis with glucocorticoids: a systematic literature review informing the EULAR recommendations for the management of rheumatoid arthritis. Ann Rheum Dis 2010, 69:1010-1014.

7. Luijten RK, Fritsch-Stork RD, Bijlsma JW, Derksen RH: The use of glucocorticoids in systemic lupus erythematosus. After 60 years still more an art than science. Autoimmun Rev 2013, 12:617-628.

8. Thiele K, Buttgereit F, Huscher D, Zink A: Current use of glucocorticoids in patients with rheumatoid arthritis in Germany. Arthritis Rheum 2005, 53:740-747.

9. Buttgereit F, Seibel MJ, Bijlsma JW: Glucocorticoids. In Clinical Immunology: Principles and Practice. 3rd edition, Chapter 87. Amsterdam: Elsevier Health Sciences; 2008

10. Sokka T, Toloza S, Cutolo M, Kautiainen H, Makinen H, Gogus F, Skakic V, Badsha H, Peets T, Baranauskaite A, Géher P, Ujfalussy I, Skopouli FN, Mavrommati M, Alten R, Pohl C, Sibilia J, Stancati A, Salaffi F, Romanowski W, Zarowny-Wierzbinska D, Henrohn D, Bresnihan B, Minnock P, Knudsen LS, Jacobs JW, Calvo-Alen J, Lazovskis J, Pinheiro Gda R, Karateev D, et al.: Women, men, and rheumatoid arthritis: analyses of disease activity, disease characteristics, and treatments in the QUEST-RA study. Arthritis Res Ther 2009, 11:R7.

11. Fardet L, Petersen I, Nazareth I: Prevalence of long-term oral glucocorticoid prescriptions in UK over the past 20 years. Rheumatology (Oxford) 2011, 50:1982-1990.

12. Walsh LJ, Wong CA, Pringle M, Tattersfield AE: Use of oral corticosteroids in the community and the prevention of secondary osteoporosis: a cross sectional study. BMJ 1996, 313:344-346.

13. Ramsey-Goldman R: Missed opportunities in physician management of glucocorticoid-induced osteoporosis? Arthritis Rheum 2002, 46:3115-3120.

14. Buttgereit $F$, Wehling M, Burmester GR: A new hypothesis of modular glucocorticoid actions: steroid treatment of rheumatic diseases revisited. Arthritis Rheum 1998, 41:761-767.

15. Buttgereit F, Straub RH, Wehling M, Burmester GR: Glucocorticoids in the treatment of rheumatic diseases: an update on the mechanisms of action. Arthritis Rheum 2004, 50:3408-3417.

16. Croxtall JD, Choudhury Q, Flower RJ: Glucocorticoids act within minutes to inhibit recruitment of signalling factors to activated EGF receptors through a receptor-dependent, transcription-independent mechanism. $\mathrm{Br}$ J Pharmacol 2000, 130:289-298.

17. Rhen T, Cidlowski JA: Antiinflammatory action of glucocorticoids - new mechanisms for old drugs. N Engl J Med 2005, 353:1711-1723.

18. Stahn C, Buttgereit F: Genomic and nongenomic effects of glucocorticoids. Nat Clin Pract Rheumatol $2008,4: 525-533$.

19. Coutinho AE, Chapman KE: The anti-inflammatory and immunosuppressive effects of glucocorticoids, recent developments and mechanistic insights. Mol Cell Endocrinol 2011, 335:2-13.

20. Buttgereit F, da Silva JA, Boers M, Burmester GR, Cutolo M, Jacobs J, Kirwan J, Kohler L, Van Riel P, Vischer T, Bijlsma JW: Standardised nomenclature for glucocorticoid dosages and glucocorticoid treatment regimens: current questions and tentative answers in rheumatology. Ann Rheum Dis 2002, 61:718-722

21. Buttgereit F, Burmester GR, Straub RH, Seibel MJ, Zhou H: Exogenous and endogenous glucocorticoids in rheumatic diseases. Arthritis Rheum 2011, 63:1-9.

22. Clark AR: Anti-inflammatory functions of glucocorticoid-induced genes. Mol Cell Endocrinol 2007, 275:79-97.

23. Kleiman A, Tuckermann JP: Glucocorticoid receptor action in beneficial and side effects of steroid therapy: lessons from conditional knockout mice. Mol Cell Endocrinol 2007, 275:98-108.

24. Hernandez-Rodriguez J, Cid MC, Lopez-Soto A, Espigol-Frigole G, Bosch X: Treatment of polymyalgia rheumatica: a systematic review. Arch Intern Med 2009, 169:1839-1850.

25. Ferraccioli G, Salaffi F, De Vita S, Casatta L, Bartoli E: Methotrexate in polymyalgia rheumatica: preliminary results of an open, randomized study. J Rheumatol 1996, 23:624-628.

26. Caporali R, Cimmino MA, Ferraccioli G, Gerli R, Klersy C, Salvarani C, Montecucco C: Prednisone plus methotrexate for polymyalgia rheumatica: a randomized, double-blind, placebo-controlled trial. Ann Intern Med 2004, 
141:493-500.

27. van der Veen MJ, Dinant $H J$, van Booma-Frankfort $C$, van Albada-Kuipers $G A$, Bijlsma JW: Can methotrexate be used as a steroid sparing agent in the treatment of polymyalgia rheumatica and giant cell arteritis? Ann Rheum Dis 1996, 55:218-223.

28. De Silva M, Hazleman BL: Azathioprine in giant cell arteritis/polymyalgia rheumatica: a double-blind study. Ann Rheum Dis 1986, 45:136-138.

29. Salvarani C, Macchioni P, Manzini C, Paolazzi G, Trotta A, Manganelli P, Cimmino M, Gerli R, Catanoso MG, Boiardi L, Cantini F, Klersy C, Hunder GG: Infliximab plus prednisone or placebo plus prednisone for the initial treatment of polymyalgia rheumatica: a randomized trial. Ann Intern Med 2007, 146:631-639.

30. Hoffman GS, Cid MC, Hellmann DB, Guillevin L, Stone JH, Schousboe J, Cohen P, Calabrese LH, Dickler H, Merkel PA, Fortin P, Flynn JA, Locker GA, Easley KA, Schned E, Hunder GG, Sneller MC, Tuggle C, Swanson H, HernándezRodríguez J, Lopez-Soto A, Bork D, Hoffman DB, Kalunian K, Klashman D, Wilke WS, Scheetz RJ, Mandell BF, Fessler BJ, Kosmorsky G, et al: A multicenter, randomized, double-blind, placebo-controlled trial of adjuvant methotrexate treatment for giant cell arteritis. Arthritis Rheum 2002, 46:1309-1318.

31. Spiera RF, Mitnick HJ, Kupersmith M, Richmond M, Spiera H, Peterson MG, Paget SA: A prospective, double-blind, randomized, placebo controlled trial of methotrexate in the treatment of giant cell arteritis (GCA). Clin Exp Rheumatol 2001, 19:495-501.

32. Jover JA, Hernandez-Garcia C, Morado IC, Vargas E, Banares A, FernandezGutierrez B: Combined treatment of giant-cell arteritis with methotrexate and prednisone. a randomized, double-blind, placebo-controlled trial. Ann Intern Med 2001, 134:106-114.

33. Schaufelberger C, Mollby H, Uddhammar A, Bratt J, Nordborg E: No additional steroid-sparing effect of cyclosporine $A$ in giant cell arteritis. Scand J Rheumatol 2006, 35:327-329.

34. Martinez-Taboada VM, Rodriguez-Valverde V, Carreno L, Lopez-Longo J, Figueroa M, Belzunegui J, Mola EM, Bonilla G: A double-blind placebo controlled trial of etanercept in patients with giant cell arteritis and corticosteroid side effects. Ann Rheum Dis 2008, 67:625-630.

35. Hoffman GS, Cid MC, Rendt-Zagar KE, Merkel PA, Weyand CM, Stone JH, Salvarani C, Xu W, Visvanathan S, Rahman MU: Infliximab for maintenance of glucocorticosteroid-induced remission of giant cell arteritis: a randomized trial. Ann Intern Med 2007, 146:621-630.

36. Diamantopoulos AP, Hetland H, Myklebust G: Leflunomide as a corticosteroid-sparing agent in giant cell arteritis and polymyalgia rheumatica: a case series. BioMed Res Int 2013, 2013:120638.

37. Weusten BL, Jacobs JW, Bijlsma JW: Corticosteroid pulse therapy in active rheumatoid arthritis. Semin Arthritis Rheum 1993, 23:183-192.

38. Janssens $H J$, Janssen $M$, van de Lisdonk EH, van Riel PL, van Weel C: Use of oral prednisolone or naproxen for the treatment of gout arthritis: a double-blind, randomised equivalence trial. Lancet 2008, 371:1854-1860.

39. Criswell LA, Saag KG, Sems KM, Welch V, Shea B, Wells G, Suarez-Almazor ME: Moderate-term, low-dose corticosteroids for rheumatoid arthritis. Cochrane Database Syst Rev 2000, 2:CD001158.

40. Gotzsche PC, Johansen HK: Short-term low-dose corticosteroids vs placebo and nonsteroidal antiinflammatory drugs in rheumatoid arthritis. Cochrane Database Syst Rev 2004, 3:CD000189.

41. Buttgereit F, Doering G, Schaeffler A, Witte S, Sierakowski S, Gromnica-Ihle E, Jeka S, Krueger K, Szechinski J, Alten R: Efficacy of modified-release versus standard prednisone to reduce duration of morning stiffness of the joints in rheumatoid arthritis (CAPRA-1): a double-blind, randomised controlled trial. Lancet 2008, 371:205-214.

42. Pincus T, Sokka T, Castrejon I, Cutolo M: Decline of mean initial prednisone dosage from 10.3 to $3.6 \mathrm{mg} /$ day to treat rheumatoid arthritis between 1980 and 2004 in one clinical setting, with long-term effectiveness of dosages less than 5 mg/day. Arthritis Care Res (Hoboken) 2013, 65:729-736.

43. Kirwan JR: The effect of glucocorticoids on joint destruction in rheumatoid arthritis. The Arthritis and Rheumatism Council Low-Dose Glucocorticoid Study Group. N Engl J Med 1995, 333:142-146.

44. Boers M, Verhoeven AC, Markusse HM, van de Laar MA, Westhovens $R$, van Denderen JC, van Zeben D, Dijkmans BA, Peeters AJ, Jacobs P, van den Brink $H R$, Schouten HJ, van der Heijde DM, Boonen A, van der Linden S: Randomised comparison of combined step-down prednisolone, methotrexate and sulphasalazine with sulphasalazine alone in early rheumatoid arthritis. Lancet 1997, 350:309-318.
45. Hansen M, Podenphant J, Florescu A, Stoltenberg M, Borch A, Kluger E, Sorensen SF, Hansen TM: A randomised trial of differentiated prednisolone treatment in active rheumatoid arthritis. Clinical benefits and skeletal side effects. Ann Rheum Dis 1999, 58:713-718.

46. van Everdingen AA, Jacobs JW, Siewertsz Van Reesema DR, Bijlsma JW: Lowdose prednisone therapy for patients with early active rheumatoid arthritis: clinical efficacy, disease-modifying properties, and side effects: a randomized, double-blind, placebo-controlled clinical trial. Ann Intern Med 2002, 136:1-12.

47. Svensson B, Boonen A, Albertsson K, van der Heijde D, Keller C, Hafstrom I: Low-dose prednisolone in addition to the initial disease-modifying antirheumatic drug in patients with early active rheumatoid arthritis reduces joint destruction and increases the remission rate: a two-year randomized trial. Arthritis Rheum 2005, 52:3360-3370

48. Wassenberg $\mathrm{S}$, Rau R, Steinfeld P, Zeidler H: Very low-dose prednisolone in early rheumatoid arthritis retards radiographic progression over two years: a multicenter, double-blind, placebo-controlled trial. Arthritis Rheum 2005, 52:3371-3380.

49. Goekoop-Ruiterman YP, de Vries-Bouwstra JK, Allaart CF, van Zeben D, Kerstens PJ, Hazes JM, Zwinderman AH, Peeters AJ, de Jonge-Bok JM, Mallée C, de Beus WM, de Sonnaville PB, Ewals JA, Breedveld FC, Dijkmans BA: Comparison of treatment strategies in early rheumatoid arthritis: a randomized trial. Ann Intern Med 2007, 146:406-415.

50. Kirwan JR, Bijlsma JW, Boers M, Shea BJ: Effects of glucocorticoids on radiological progression in rheumatoid arthritis. Cochrane Database Syst Rev 2007, 1:CD006356.

51. Choy EH, Smith CM, Farewell V, Walker D, Hassell A, Chau L, Scott DL: Factorial randomised controlled trial of glucocorticoids and combination disease modifying drugs in early rheumatoid arthritis. Ann Rheum Dis 2008, 67:656-663

52. Bakker MF, Jacobs JW, Welsing PM, Verstappen SM, Tekstra J, Ton E, Geurts MA, van der Werf JH, van Albada-Kuipers GA, Jahangier-de Veen ZN, van der Veen MJ, Verhoef CM, Lafeber FP, Bijlsma JW; Utrecht Rheumatoid Arthritis Cohort Study Group: Low-dose prednisone inclusion in a methotrexate-based, tight control strategy for early rheumatoid arthritis: a randomized trial. Ann Intern Med 2012, 156:329-339.

53. Hafstrom I, Albertsson K, Boonen A, van der Heijde D, Landewe R, Svensson B: Remission achieved after 2 years treatment with low-dose prednisolone in addition to disease-modifying anti-rheumatic drugs in early rheumatoid arthritis is associated with reduced joint destruction still present after 4 years: an open 2-year continuation study. Ann Rheum Dis 2009, 68:508-513.

54. Jacobs JW, van Everdingen AA, Verstappen SM, Bijlsma JW: Followup radiographic data on patients with rheumatoid arthritis who participated in a two-year trial of prednisone therapy or placebo. Arthritis Rheum 2006, 54:1422-1428

55. Landewe RB, Boers M, Verhoeven AC, Westhovens $R$, van de Laar MA, Markusse HM, van Denderen JC, Westedt ML, Peeters AJ, Dijkmans BA, Jacobs $P$, Boonen A, van der Heijde DM, van der Linden S: COBRA combination therapy in patients with early rheumatoid arthritis: long-term structural benefits of a brief intervention. Arthritis Rheum 2002, 46:347-356.

56. Smolen JS, Landewe R, Breedveld FC, Buch M, Burmester G, Dougados M, Emery P, Gaujoux-Viala C, Gossec L, Nam J, Ramiro S, Winthrop K, de Wit M, Aletaha D, Betteridge N, Biilsma JW, Boers M, Buttgereit F, Combe B, Cutolo M, Damjanov N, Hazes JM, Kouloumas M, Kvien TK, Mariette X, Pavelka K, van Riel PL, Rubbert-Roth A, Scholte-Voshaar M, Scott DL, et al: EULAR recommendations for the management of rheumatoid arthritis with synthetic and biological disease-modifying antirheumatic drugs: 2013 update. Ann Rheum Dis 2014, 73:492-509.

57. Singh JA, Furst DE, Bharat A, Curtis JR, Kavanaugh AF, Kremer JM, Moreland LW, O'Dell J, Winthrop KL, Beukelman T, Bridges SL Jr, Chatham WW, Paulus HE, Suarez-Almazor M, Bombardier C, Dougados M, Khanna D, King CM, Leong AL, Matteson EL, Schousboe JT, Moynihan E, Kolba KS, Jain A, Volkmann ER, Agrawal H, Bae S, Mudano AS, Patkar NM, Saag KG: 2012 update of the 2008 American College of Rheumatology recommendations for the use of disease-modifying antirheumatic drugs and biologic agents in the treatment of rheumatoid arthritis. Arthritis Care Res (Hoboken) 2012 64:625-639.

58. Boers M, Kirwan JR, Bijlsma JW: American College of Rheumatology treatment guidelines continue to omit guidance on glucocorticoids: comment on the article by Singh et al. Arthritis Care Res (Hoboken) 2012, 64:1622. 
59. Gaffney K, Ledingham J, Perry JD: Intra-articular triamcinolone hexacetonide in knee osteoarthritis: factors influencing the clinical response. Ann Rheum Dis 1995, 54:379-381.

60. Blyth T, Hunter JA, Stirling A: Pain relief in the rheumatoid knee after steroid injection. A single-blind comparison of hydrocortisone succinate, and triamcinolone acetonide or hexacetonide. Br J Rheumatol 1994, 33:461-463.

61. Chakravarty K, Pharoah PD, Scott DG: A randomized controlled study of post-injection rest following intra-articular steroid therapy for knee synovitis. Br J Rheumatol 1994, 33:464-468.

62. McCarty DJ, Harman JG, Grassanovich JL, Qian C: Treatment of rheumatoid joint inflammation with intrasynovial triamcinolone hexacetonide. $J$ Rheumatol 1995, 22:1631-1635.

63. Bijlsma JWJ, Buttgereit F, Jacobs JWG: Systemic and intra-articular glucocorticoids in rheumatoid arthritis. In Rheumatoid Arthritis. 2nd edition. Oxford: Oxford University Press; 2007:337-353.

64. Saag KG, Koehnke R, Caldwell JR, Brasington R, Burmeister LF, Zimmerman B, Kohler JA, Furst DE: Low dose long-term corticosteroid therapy in rheumatoid arthritis: an analysis of serious adverse events. Am J Med 1994, 96:115-123

65. Huscher D, Thiele K, Gromnica-Ihle E, Hein G, Demary W, Dreher R, Zink A, Buttgereit F: Dose-related patterns of glucocorticoid-induced side effects. Ann Rheum Dis 2009, 68:1119-1124.

66. Bijlsma JW, Saag KG, Buttgereit F, da Silva JA: Developments in glucocorticoid therapy. Rheum Dis Clin North Am 2005, 31:1-17, vii.

67. Da Silva JA, Jacobs JW, Kirwan JR, Boers M, Saag KG, Ines LB, de Koning EJ, Buttgereit F, Cutolo M, Capell H, Rau R, Biilsma JW: Safety of low dose glucocorticoid treatment in rheumatoid arthritis: published evidence and prospective trial data. Ann Rheum Dis 2006, 65:285-293.

68. Hoes JN, Jacobs JW, Boers M, Boumpas D, Buttgereit F, Caeyers N, Choy EH, Cutolo M, Da Silva JA, Esselens G, Guillevin L, Hafstrom I, Kirwan JR, Rovensky J, Russell A, Saag KG, Svensson B, Westhovens R, Zeidler H, Biilsma JW: EULAR evidence-based recommendations on the management of systemic glucocorticoid therapy in rheumatic diseases. Ann Rheum Dis 2007, 66:1560-1567

69. van der Goes MC, Jacobs JW, Boers M, Andrews T, Blom-Bakkers MA Buttgereit F, Caeyers N, Cutolo M, Da Silva JA, Guillevin L, Kirwan JR, Rovensky J, Severijns G, Webber S, Westhovens R, Bijlsma JW: Monitoring adverse events of low-dose glucocorticoid therapy: EULAR recommendations for clinical trials and daily practice. Ann Rheum Dis 2010, 69:1913-1919.

70. Duru N, van der Goes MC, Jacobs JW, Andrews T, Boers M, Buttgereit F, Caeyers N, Cutolo M, Halliday S, Da Silva JA, Kirwan JR, Ray D, Rovensky J, Severijns G, Westhovens R, Bijlsma JW: EULAR evidence-based and consensus-based recommendations on the management of medium to high-dose glucocorticoid therapy in rheumatic diseases. Ann Rheum Dis 2013, 72:1905-1913

71. van Staa TP, Leufkens HG, Cooper C: The epidemiology of corticosteroidinduced osteoporosis: a meta-analysis. Osteoporos Int 2002, 13:777-787.

72. Keller C, Hafstrom I, Svensson B: Bone mineral density in women and men with early rheumatoid arthritis. Scand J Rheumatol 2001, 30:213-220.

73. Shenstone BD, Mahmoud A, Woodward R, Elvins D, Palmer R, Ring EF, Bhalla AK: Longitudinal bone mineral density changes in early rheumatoid arthritis. Br J Rheumatol 1994, 33:541-545.

74. Book C, Karlsson M, Akesson K, Jacobsson L: Disease activity and disability but probably not glucocorticoid treatment predicts loss in bone mineral density in women with early rheumatoid arthritis. Scand J Rheumatol 2008, 37:248-254

75. Forslind K, Keller C, Svensson B, Hafstrom I: Reduced bone mineral density in early rheumatoid arthritis is associated with radiological joint damage at baseline and after 2 years in women. J Rheumatol 2003, 30:2590-2596.

76. Gough AK, Lilley J, Eyre S, Holder RL, Emery P: Generalised bone loss in patients with early rheumatoid arthritis. Lancet 1994, 344:23-27.

77. van der Goes MC, Jacobs JW, Jurgens MS, Bakker MF, van der Veen MJ, van der Werf JH, Welsing PM, Bijlsma JW: Are changes in bone mineral density different between groups of early rheumatoid arthritis patients treated according to a tight control strategy with or without prednisone if osteoporosis prophylaxis is applied? Osteoporos Int 2013, 24:1429-1436.

78. Bezerra MC, Carvalho JF, Prokopowitsch AS, Pereira RM: RANK, RANKL and osteoprotegerin in arthritic bone loss. Braz J Med Biol Res 2005, 38:161-170

79. Miyasaka N, Sato K, Goto M, Sasano M, Natsuyama M, Inoue K, Nishioka K: Augmented interleukin-1 production and HLA-DR expression in the synovium of rheumatoid arthritis patients. Possible involvement in joint destruction. Arthritis Rheum 1988, 31:480-486.

80. Mabilleau G, Pascaretti-Grizon F, Basle MF, Chappard D: Depth and volume of resorption induced by osteoclasts generated in the presence of RANKL, TNF-alpha/IL-1 or LIGHT. Cytokine 2012, 57:294-299.

81. Jacobs JW, Geenen R, Evers AW, van Jaarsveld CH, Kraaimaat FW, Bijlsma JW: Short term effects of corticosteroid pulse treatment on disease activity and the wellbeing of patients with active rheumatoid arthritis. Ann Rheum Dis 2001, 60:61-64.

82. Jurgens MS, Jacobs JW, Geenen R, Bossema ER, Bakker MF, Bijlsma JW, van Albada-Kuipers IA, Ehrlich JC, Lafeber FP, Welsing PM: Increase of body mass index in a tight controlled methotrexate-based strategy with prednisone in early rheumatoid arthritis: side effect of the prednisone or better control of disease activity? Arthritis Care Res (Hoboken) 2013, 65:88-93.

83. van der Goes MC, Jacobs JW, Boers M, Andrews T, Blom-Bakkers MA Buttgereit F, Caeyers N, Choy EH, Cutolo M, Da Silva JA, Guillevin L, Holland M, Kirwan JR, Rovensky J, Saag KG, Severijns G, Webber S, Westhovens R, Bijlsma $J W:$ Patient and rheumatologist perspectives on glucocorticoids: an exercise to improve the implementation of the European League Against Rheumatism (EULAR) recommendations on the management of systemic glucocorticoid therapy in rheumatic diseases. Ann Rheum Dis 2010, 69:1015-1021

84. Saltiel AR, Kahn CR: Insulin signalling and the regulation of glucose and lipid metabolism. Nature 2001, 414:799-806.

85. Peters MJ, Symmons DP, McCarey D, Dijkmans BA, Nicola P, Kvien TK, Mclnnes IB, Haentzschel H, Gonzalez-Gay MA, Provan S, Semb A, Sidiropoulos P, Kitas G, Smulders YM, Soubrier M, Szekanecz Z, Sattar N, Nurmohamed MT: EULAR evidence-based recommendations for cardiovascular risk management in patients with rheumatoid arthritis and other forms of inflammatory arthritis. Ann Rheum Dis 2010, 69:325-331.

86. Ku IA, Imboden JB, Hsue PY, Ganz P: Rheumatoid arthritis: model of systemic inflammation driving atherosclerosis. Circ J 2009, 73:977-985.

87. Hajer GR, van Haeften TW, Visseren FL: Adipose tissue dysfunction in obesity, diabetes, and vascular diseases. Eur Heart J 2008, 29:2959-2971.

88. Dessein PH, Joffe BI: Insulin resistance and impaired beta cell function in rheumatoid arthritis. Arthritis Rheum 2006, 54:2765-2775.

89. Chung CP, Oeser A, Solus JF, Gebretsadik T, Shintani A, Avalos I, Sokka T, Raggi $P$, Pincus T, Stein CM: Inflammation-associated insulin resistance: differential effects in rheumatoid arthritis and systemic lupus erythematosus define potential mechanisms. Arthritis Rheum 2008, 58:2105-2112

90. Shahin $\mathrm{D}$, Eltoraby $\mathrm{E}$, Mesbah $\mathrm{A}$, Houssen $\mathrm{M}$ : Insulin resistance in early untreated rheumatoid arthritis patients. Clin Biochem 2010, 43:661-665.

91. den Uyl D, van Raalte DH, Nurmohamed MT, Lems WF, Bijlsma JW, Hoes JN Dijkmans BA, Diamant M: Metabolic effects of high-dose prednisolone treatment in early rheumatoid arthritis: balance between diabetogenic effects and inflammation reduction. Arthritis Rheum 2012, 64:639-646.

92. Hoes JN, van der Goes MC, van Raalte DH, van der Zijl NJ, den Uyl D, Lems WF, Lafeber FP, Jacobs JW, Welsing PM, Diamant M, Bijlsma JW: Glucose tolerance, insulin sensitivity and beta-cell function in patients with rheumatoid arthritis treated with or without low-to-medium dose glucocorticoids. Ann Rheum Dis 2011, 70:1887-1894.

93. Charmandari E, Nicolaides NC, Chrousos GP: Adrenal insufficiency. Lancet 2014, 383:2152-2167.

94. EMPIRE Rheumatism Council: multi-centre controlled trial comparing cortisone acetate and acetyl salicylic acid in the long-term treatment of rheumatoid arthritis; results of three years' treatment. Ann Rheum Dis 1957, 16:277-289

95. A COMPARISON of prednisolone with aspirin on other analgesics in the treatment of rheumatoid arthritis. Ann Rheum Dis 1959, 18:173-188.

96. Dixon WG, Kezouh A, Bernatsky S, Suissa S: The influence of systemic glucocorticoid therapy upon the risk of non-serious infection in older patients with rheumatoid arthritis: a nested case-control study. Ann Rheum Dis 2011, 70:956-960.

97. Dixon WG, Abrahamowicz M, Beauchamp ME, Ray DW, Bernatsky S, Suissa S, Sylvestre MP: Immediate and delayed impact of oral glucocorticoid therapy on risk of serious infection in older patients with rheumatoid arthritis: a nested case-control analysis. Ann Rheum Dis 2012, 71:1128-1133

98. Widdifield J, Bernatsky S, Paterson JM, Gunraj N, Thorne JC, Pope J, Cividino A, Bombardier C: Serious infections in a population-based cohort of 86,039 seniors with rheumatoid arthritis. Arthritis Care Res (Hoboken) 2013, 
65:353-361

99. Crowson CS, Hoganson DD, Fitz-Gibbon PD, Matteson EL: Development and validation of a risk score for serious infection in patients with rheumatoid arthritis. Arthritis Rheum 2012, 64:2847-2855.

100. Yale SH, Limper AH: Pneumocystis carinii pneumonia in patients without acquired immunodeficiency syndrome: associated illness and prior corticosteroid therapy. Mayo Clin Proc 1996, 71:5-13.

101. Belard E, Semb S, Ruhwald M, Werlinrud AM, Soborg B, Jensen FK, Thomsen H, Brylov A, Hetland ML, Nordgaard-Lassen I, Ravn P: Prednisolone treatment affects the performance of the QuantiFERON gold in-tube test and the tuberculin skin test in patients with autoimmune disorders screened for latent tuberculosis infection. Inflamm Bowel Dis 2011, 17:2340-2349.

102. van Assen S, Agmon-Levin N, Elkayam O, Cervera R, Doran MF, Dougados M, Emery P, Geborek P, loannidis JP, Jayne DR, Kallenberg CG, Müller-Ladner U, Shoenfeld Y, Stojanovich L, Valesini G, Wulffraat NM, Bijl M: EULAR recommendations for vaccination in adult patients with autoimmune inflammatory rheumatic diseases. Ann Rheum Dis 2011, 70:414-422.

103. Garcia Rodriguez LA, Hernandez-Diaz S: The risk of upper gastrointestinal complications associated with nonsteroidal anti-inflammatory drugs, glucocorticoids, acetaminophen, and combinations of these agents. Arthritis Res 2001, 3:98-101.

104. Piper JM, Ray WA, Daugherty JR, Griffin MR: Corticosteroid use and peptic ulcer disease: role of nonsteroidal anti-inflammatory drugs. Ann Intern Med 1991, 114:735-740.

105. Deeks JJ, Smith LA, Bradley MD: Efficacy, tolerability, and upper gastrointestinal safety of celecoxib for treatment of osteoarthritis and rheumatoid arthritis: systematic review of randomised controlled trials. BMJ 2002, 325:619.

106. Silverstein FE, Faich G, Goldstein JL, Simon LS, Pincus T, Whelton A, Makuch R, Eisen G, Agrawal NM, Stenson WF, Burr AM, Zhao WW, Kent JD, Lefkowith JB, Verburg KM, Geis GS: Gastrointestinal toxicity with celecoxib vs nonsteroidal anti-inflammatory drugs for osteoarthritis and rheumatoid arthritis: the CLASS study: a randomized controlled trial. Celecoxib Longterm Arthritis Safety Study. JAMA 2000, 284:1247-1255.

107. Bombardier C, Laine L, Reicin A, Shapiro D, Burgos-Vargas R, Davis B, Day R, Ferraz MB, Hawkey CJ, Hochberg MC, Kvien TK, Schnitzer TJ; VIGOR Study Group: Comparison of upper gastrointestinal toxicity of rofecoxib and naproxen in patients with rheumatoid arthritis. VIGOR Study Group. N Engl J Med 2000, 343:1520-1528; 2 pp following 1528.

108. Cooper C, Kirwan JR: The risks of local and systemic corticosteroid administration. Baillieres Clin Rheumatol 1990, 4:305-332.

109. Carnahan MC, Goldstein DA: Ocular complications of topical, peri-ocular, and systemic corticosteroids. Curr Opin Ophthalmol 2000, 11:478-483.

110. Homik J, Suarez-Almazor ME, Shea B, Cranney A, Wells G, Tugwell P: Calcium and vitamin D for corticosteroid-induced osteoporosis. Cochrane Database Syst Rev 2000, 2:CD000952.

111. Homik J, Cranney A, Shea B, Tugwell P, Wells G, Adachi R, Suarez-Almazor M: Bisphosphonates for steroid induced osteoporosis. Cochrane Database Syst Rev 2000, 2:CD001347.

112. Amin S, Lavalley MP, Simms RW, Felson DT: The comparative efficacy of drug therapies used for the management of corticosteroid-induced osteoporosis: a meta-regression. J Bone Miner Res 2002, 17:1512-1526.

113. de Nijs RN, Jacobs JW, Lems WF, Laan RF, Algra A, Huisman AM, Buskens E, de Laet CE, Oostveen AC, Geusens PP, Bruyn GA, Dijkmans BA, Bijlsma JW; STOP Investigators: Alendronate or alfacalcidol in glucocorticoid-induced osteoporosis. N Engl J Med 2006, 355:675-684.

114. de Nijs RN, Jacobs JW, Algra A, Lems WF, Bijlsma JW: Prevention and treatment of glucocorticoid-induced osteoporosis with active vitamin D3 analogues: a review with meta-analysis of randomized controlled trials including organ transplantation studies. Osteoporos Int 2004, 15:589-602.

115. Richy F, Schacht E, Bruyere O, Ethgen O, Gourlay M, Reginster JY: Vitamin D analogs versus native vitamin $\mathrm{D}$ in preventing bone loss and osteoporosis-related fractures: a comparative meta-analysis. Calcif Tissue Int 2005, 76:176-186.

116. FRAX [https://www.shef.ac.uk/FRAX/]

117. Grossman JM, Gordon R, Ranganath VK, Deal C, Caplan L, Chen W, Curtis JR, Furst DE, McMahon M, Patkar NM, Volkmann E, Saag KG: American College of Rheumatology 2010 recommendations for the prevention and treatment of glucocorticoid-induced osteoporosis. Arthritis Care Res (Hoboken) 2010, 62:1515-1526.

118. van Staa TP, Geusens P, Pols HA, de Laet C, Leufkens HG, Cooper C: A simple score for estimating the long-term risk of fracture in patients using oral glucocorticoids. QJM 2005, 98:191-198.

119. Kanis JA, McCloskey EV, Johansson H, Strom O, Borgstrom F, Oden A: Case finding for the management of osteoporosis with FRAX - assessment and intervention thresholds for the UK. Osteoporos Int 2008, 19:1395-1408.

120. Kanis JA, Johnell O, Oden A, Johansson H, McCloskey E: FRAX and the assessment of fracture probability in men and women from the UK. Osteoporos Int 2008, 19:385-397.

121. McCloskey E, Kanis JA: FRAX updates 2012. Curr Opin Rheumato/2012, 24:554-560.

122. Park-Wyllie L, Mazzotta P, Pastuszak A, Moretti ME, Beique L, Hunnisett L, Friesen MH, Jacobson S, Kasapinovic S, Chang D, Diav-Citrin O, Chitayat D, Nulman I, Einarson TR, Koren G: Birth defects after maternal exposure to corticosteroids: prospective cohort study and meta-analysis of epidemiological studies. Teratology 2000, 62:385-392.

123. Temprano KK, Bandlamudi R, Moore TL: Antirheumatic drugs in pregnancy and lactation. Semin Arthritis Rheum 2005, 35:112-121.

124. Schacke $H$, Berger M, Rehwinkel $H$, Asadullah K: Selective glucocorticoid receptor agonists (SEGRAs): novel ligands with an improved therapeutic index. Mol Cell Endocrinol 2007, 275:109-117.

125. Strehl C, Spies CM, Buttgereit F: Pharmacodynamics of glucocorticoids. Clin Exp Rheumatol 2011, 29:S13-S18

126. Reuter KC, Grunwitz CR, Kaminski BM, Steinhilber D, Radeke HH, Stein J: Selective glucocorticoid receptor agonists for the treatment of inflammatory bowel disease: studies in mice with acute trinitrobenzene sulfonic acid colitis. J Pharmacol Exp Ther 2012, 341:68-80.

127. Hoes JN, Jacobs JW, Buttgereit F, Bijlsma JW: Current view of glucocorticoid co-therapy with DMARDs in rheumatoid arthritis. Nat Rev Rheumatol 2010, 6:693-702.

128. Huisman AM, Jacobs JW, Buttgereit F, Bijlsma JW: [New developments in glucocorticoid therapy: selective glucocorticoid receptor agonists, nitrosteroids and liposomal glucocorticoids]. Ned Tijdschr Geneeskd 2006, 150:476-480.

129. Jacobs JW, van der Goes MC, Buttgereit F: Glucocorticoids in rheumatic diseases. In EULAR Textbook on Rheumatic Diseases. Edited by Bijlsma JWJ. London: BMJ Group; 2012:1218-1233.

130. Kuchuk NO, Hoes JN, Bijlsma JW, Jacobs JW: Glucocorticoid-induced osteoporosis: an overview. Int J Clin Rheumatol 2014, 9:311-326.

\section{doi:10.1186/ar4686}

Cite this article as: ven der Goes MC, et al:: The value of glucocorticoid co-therapy in different rheumatic diseases - positive and adverse effects. Arthritis Research \& Therapy 2014, 16(Suppl 2):S2. 